\title{
Association between human parvovirus B19 infection and arthritis
}

\author{
P Cassinotti, S Bas, G Siegl, T L Vischer
}

\begin{abstract}
Objective-To gain information concerning the association between parvovirus $B 19$ infection and arthritis.

Methods-Blood or synovial fluid, or both, from a total of 77 adult patients with various arthropathies (rheumatoid arthritis 13; mechanical arthropathies 11; crystal induced arthritis 13; idiopathic mono/oligoarthritis 25; suspicion of viral arthritis 15) were tested for the presence of the viral genome and anti-B19 antibodies. B19 DNA in blood and synovial fluid was investigated by nested polymerase chain reaction, and anti-B19 IgM and IgG antibodies were detected in blood by enzyme immunoassay.

Results-A recent parvovirus infection was documented by the presence of anti-B19 IgM antibodies in the blood of 13 patients. B19 DNA, together with anti-B19 IgM and IgG antibodies, were detected in the blood of seven patients who had an acute transient arthritis, putatively of viral origin. Viral DNA was detected in a synovial fluid sample and in the blood of one patient with monoarthritis who had an anti-B19 IgG response only.

Conclusions-The prevalence of anti-B19 IgG antibody in these patients with various forms of arthritis $(63 \%)$ was within the same range as that in the general population (blood donors). However, for the patients with clinical suspicion of viral arthritis, the increased seroprevalence of anti-B19 IgM and the presence of the B19 genome point to an association between human parvovirus infections and acute forms of arthritis.
\end{abstract}

(Ann Rheum Dis 1995; 54: 498-500)

Human parvovirus $\mathrm{B} 19$ is known as the aetiological agent of erythema infectiosum, a well known disease of childhood. However, in both children and adults, B19 virus infections may frequently take an atypical or asymptomatic course, a common sequela of both courses being the appearance of arthralgias and arthritis. ${ }^{1-5}$ The respective clinical symptoms generally resolve within a few weeks, but arthritis may also take a prolonged course putatively associated with persistent B19 infections, as revealed by demonstration of B19 DNA in various body fluids. ${ }^{6-8}$ In patients with a clinical diagnosis of viral arthritis, the association with parvovirus
B19 may nevertheless be difficult to establish, particularly in the absence of classical manifestations. In order to gain more information concerning the association between parvovirus B19 infection and arthritis, we have tested blood, synovial fluid, or both, from 77 adult patients with various forms of arthritis for the presence of the viral genome and anti-B19 antibodies, using nested polymerase chain reaction (PCR) and enzyme immunoassay (EIA), respectively.

\section{Patients and methods}

The samples of serum, synovial fluid, or both, were among the more recent additions to our Geneva regional sample bank, from a total of 77 adult patients with the following diagnoses: 13 with rheumatoid arthritis (with rheumatoid factor); 13 with crystal induced arthritis (four gout, nine chondrocalcinosis), 11 with a mechanical arthropathy (five osteoarthrosis, four torn meniscus, two trauma); 25 patients had an idiopathic, mono/oligoarthritis (up to four joints) without rheumatoid factors which did not fulfill the criteria of any defined rheumatic disease. All these diagnoses had been established at least one year earlier. In 15 patients there was a clinical suspicion of viral arthritis (acute onset with fever, sore throat, myalgias, arthralgias, arthritis, and sometimes a rash). These cases occurred within one year, without any regional clustering.

DNA was obtained from serum by heating and from synovial fluid by treatment with proteinase $\mathrm{K}$ as previously described. ${ }^{9}$ After isolation of DNA, a nucleic acid fragment within the sequence coding for the major capsid protein (VP2) of parvovirus B19 was amplified by nested polymerase chain reaction (PCR). ${ }^{9}$ Briefly, the first amplification consisted of 35 cycles using the outer primers TJI (nucleotide 3775-3792, 5'-TTCTTTTCAGCTTTTAGG-3') and TIII (nucleotide 3956-3975, 3'-GTACTTCTGGTACGTTAAGT-5') numbered according to Shade et al. ${ }^{10}$ The second round of amplification consisted of 35 cycles using the inner primers 968 (nucleotide 3818-3837, 5'-TATAAGTTTCCTCCAGTGCC-3') and 967b (nucleotide 3920-3938, 3'-TGTAATCCTCCACTGGGTT-5'). PCR products were analysed by agarose gel electrophoresis. A negative control for the DNA extraction was included in each PCR run. Each fourth sample was a negative control for the PCR reaction containing no DNA. The samples were coded and each sample analysed in duplicate.

Switzerland. 
Table 1 Serological markers for parvovirus B19 and genome detection in blood, synovial fluid, or both, from patients with various types of arthritis

\begin{tabular}{|c|c|c|c|c|c|c|}
\hline \multirow[t]{2}{*}{ Arthritis category } & \multicolumn{4}{|l|}{ Anti-B19 antibodies } & \multicolumn{2}{|c|}{ Patients with B19 DNA } \\
\hline & $\begin{array}{l}\text { IgM+ } \\
\text { IgG- }\end{array}$ & $\begin{array}{l}\operatorname{IgM} M+ \\
\operatorname{IgG+}\end{array}$ & $\begin{array}{l}\text { IgM- } \\
\text { IgG+ }\end{array}$ & $\begin{array}{l}\text { IgM- } \\
\text { IgG- }\end{array}$ & in serum & in synovial fluid \\
\hline $\begin{array}{l}\text { Rheumatoid arthritis } \\
\text { (with rheumatoid factors) } \\
\text { Crystal induced arthritis } \\
\text { Mechanical arthropathies } \\
\text { Idiopathic mono/oligoarthritis } \\
\text { Viral arthritis }\end{array}$ & $\begin{array}{l}0(0 \%)(n=4) \\
1(14 \%)(n=7) \\
0(0 \%)(n=7) \\
2(9 \cdot 5 \%)(n=21) \\
0(0 \%)(n=15)\end{array}$ & $\begin{array}{l}0(0 \%)(\mathrm{n}=4) \\
0(0 \%)(\mathrm{n}=7) \\
0(0 \%)(\mathrm{n}=7) \\
2(9 \cdot 5 \%)(\mathrm{n}=21) \\
8(53 \%)(\mathrm{n}=15)\end{array}$ & $\begin{array}{l}3(75 \%)(n=4) \\
2(29 \%)(n=7) \\
4(57 \%)(n=7) \\
9(43 \%)(n=21) \\
6(40 \%)(n=15)\end{array}$ & $\begin{array}{l}1(25 \%)(n=4) \\
4(57 \%)(n=7) \\
3(43 \%)(n=7) \\
8(38 \%)(n=21) \\
1(7 \%)(n=15)\end{array}$ & $\begin{array}{l}0(0 \%)(n=4) \\
0(0 \%)(n=7) \\
0(0 \%)(n=7) \\
1(5 \%)(n=21) \\
7(47 \%)(n=15)\end{array}$ & $\begin{array}{l}0(0 \%)(n=12) \\
0(0 \%)(n=12) \\
0(0 \%)(n=10) \\
1(6 \%)(n=16) \\
\text { NA }\end{array}$ \\
\hline Total & $3(6 \%)(n=54)$ & $10(19 \%)(n=54)$ & $24(44 \%)(n=54)$ & $17(31 \%)(n=54)$ & $8(15 \%)(n=54)$ & $1(2 \%)(n=50)$ \\
\hline
\end{tabular}

$\mathrm{n}=$ Number of patients tested;

NA = no material available.

Blood samples were tested for the presence of anti-B19 IgM and IgG antibody using a commercially available enzyme linked immunosorbentassay (IBL, Parvovirus IgM/IgG ELISA, Gesellschaft für Immunchemie und Immunbiologie MBH, Hamburg, Germany).

\section{Results}

Fifty four of the 77 patients from the Geneva region were tested for the presence of anti-B19 antibodies in serum (table 1$) ; 34(63 \%)$ had anti-B19 IgG antibodies with or without anti-B19 IgM antibodies. This seroprevalence agrees with our own unpublished observations and those reported elsewhere. ${ }^{11} 12$ The greatest prevalence was observed in the group of patients with viral arthritis, suspected on clinical grounds (93\%). Anti-B19 IgM antibodies indicative of a recent infection were detected with or without anti-B19 IgG antibodies in $13(25 \%)$ of the 54 patients tested. Eight of them were in the group with suspected viral arthritis. Interestingly, four patients in the group with unclassified mono/oligoarthritis also had serological evidence of a recent infection with parvovirus B19. Only one patient in a control group (crystal induced arthritis category) had IgM antibodies. This patient had classical gout, with an acute attack at the time of study. No anti-B19 IgM antibodies were detected in the blood of patients in the rheumatoid arthritis or mechanical arthropathy categories.
The coded samples analysed by PCR were decoded and sorted after the PCR results were available. No contamination was recorded and identical results were obtained between duplicates. B19 DNA was detected by PCR in the blood of eight of the 54 patients (tables 1,2); among them, seven had a clinical diagnosis of viral arthritis and their blood contained anti-B19 IgM and IgG antibodies together with the viral genome. In one patient (Zia, table 2), a second serum sample had been obtained five weeks after the first, and still contained the viral genome and IgG antibodies, but IgM antibodies were no longer present. Unfortunately, no synovial fluid samples were available from the patients with suspected viral arthritis. The only other patient whose blood contained parvovirus DNA (a 36 year old man (Fer, table 2)) belonged to the group of idiopathic mono/ oligoarthritis; anti-B19 IgG antibodies but no anti-B19 IgM antibodies were detected. This patient had a knee arthritis of six months duration, without any constitutional symptoms at the time the samples were taken. This was the only patient in whom we found the parvovirus $\mathrm{B} 19$ genome in synovial fluid also.

\section{Discussion}

In this study, B19 infection was specifically documented in patients with clinical suspicion of viral arthritis. These patients often lacked typical features of a parvovirus infection such

Table 2 Patients with B19 genome in their blood: correlation of genome detection and serological markers for B19

\begin{tabular}{|c|c|c|c|c|c|}
\hline $\begin{array}{l}\text { Patient } \\
\text { (sex/age (yr)) }\end{array}$ & Category & $\operatorname{Ig} M$ & $\operatorname{Ig} G$ & $D N A$ & Clinical findings \\
\hline $\operatorname{Fer}(M / 36)$ & $\begin{array}{l}\text { Idiopathic } \\
\text { mono/oligoarthritis }\end{array}$ & - & + & $+t$ & $\begin{array}{l}\text { Sample at } 6 \text { months } \\
\text { Knee arthritis for } 6 \text { months; lost to follow up }\end{array}$ \\
\hline $\operatorname{AvM}(\mathrm{F} / 32)$ & Viral arthritis & + & + & + & $\begin{array}{l}\text { Sample at } 1 \text { week } \\
\text { Rash; febrile gonarthritis during } 1 \text { week }\end{array}$ \\
\hline $\operatorname{AvR}^{\star}(M / 36)$ & Viral arthritis & + & + & + & $\begin{array}{l}\text { Sample at } 1 \text { week } \\
\text { Rash; febrile polyarthralgias during } 1 \text { week }\end{array}$ \\
\hline $\mathrm{Cal}(\mathrm{F} / 40)$ & Viral arthritis & $\begin{array}{l}+ \\
+\end{array}$ & $\begin{array}{l}+ \\
+\end{array}$ & $\begin{array}{l}+ \\
+\end{array}$ & $\begin{array}{l}\text { Sample at } 2 \text { weeks } \\
\text { Febrile polyarthralgias during } 6 \text { weeks } \\
\text { Sample at } 5 \text { weeks }\end{array}$ \\
\hline Csu (F/27) & Viral arthritis & + & + & + & $\begin{array}{l}\text { Sample at } 3 \text { days } \\
\text { Febrile polyarthralgias during } 1 \text { week }\end{array}$ \\
\hline $\operatorname{Daf}(M / 38)$ & Viral arthritis & + & + & + & $\begin{array}{l}\text { Sample at } 2 \text { days } \\
\text { Febrile polyarthritis during } 10 \text { days }\end{array}$ \\
\hline $\operatorname{Pac}(F / 36)$ & Viral arthritis & + & + & + & $\begin{array}{l}\text { Sample at } 1 \text { week } \\
\text { Febrile symmetric polyarthritis during } 10 \text { days }\end{array}$ \\
\hline Zia $(F / 43)$ & Viral arthritis & + & $\begin{array}{l}+ \\
+\end{array}$ & $\begin{array}{l}+ \\
+\end{array}$ & $\begin{array}{l}\text { Sample at } 3 \text { weeks } \\
\text { Rash; febrile symmetric polyarthritis during } 6 \text { weeks } \\
\text { Sample at } 8 \text { weeks }\end{array}$ \\
\hline
\end{tabular}


as an itching rash or symmetric arthritis involving small joints. However, because as many as eight of 15 patients with clinical suspicion of viral arthritis showed evidence of recent parvovirus B19 infection, it is very likely that human parvovirus B19, in addition to other viruses including those causing rubella and mumps, is a frequent infectious cause of arthritis. The difference in the proportion of parvovirus B19 infection in patients with suspected viral arthritis compared with the other categories was statistically highly significant (Fisher's exact probability test; $\mathrm{p}=0.0005$ ).

Whereas the presence of anti-B19 IgM antibody usually indicates a recent parvovirus infection, the sole presence of anti-B19 IgG antibodies is considered indicative of past infection and immunity. ${ }^{1314}$ In the normal host, anti-B19 IgM antibody usually does not persist longer than one to three months ${ }^{15}$ and the rapid decline of this antibody to undetectable levels consequently impairs serological diagnosis of a B19 infection in patients with arthritis persisting beyond that period. This was evident in the follow up of one patient (Zia, table 2) in the viral arthritis category for whom anti-B19 IgM antibodies were no longer detectable in a follow up blood sample collected five weeks after the first one, when she still had persisting arthritis of one wrist, although the viral genome and anti-B19 IgG antibody were still present. It is possible that the failure to detect anti-B19 IgM antibodies in the later serum sample was also related to the lack of sensitivity of the test system used. This may also explain the findings in the patient with knee arthritis of six months duration (Fer, table 2), although a chronic parvovirus B19 infection or a coincidental infection cannot be excluded.

Certainly, in late presenting cases the absence of anti-B19 IgM antibodies does not exclude an association between human parvovirus infection and acute arthritis. The number of patients presenting with an acute parvovirus B19 infection may therefore have been under- estimated on the basis of serological data. In this context, a PCR assay for B19 may not only facilitate the diagnosis of a parvovirus B19 infection, but also allow clarification of the role played by parvovirus B19 in both acute and chronic arthritis. As acute arthritis related to parvovirus B19 infection might persist for months or longer, specific diagnosis is of clinical significance.

We thank Susanne Nigg for excellent technical assistance.

1 Reid D M, Reid T M S, Brown T, Rennie J A N, Eastmond C J. Human parvovirus-associated arthritis: a clinical and laboratory description. Lancet 1985; ii: 422-5.

2 White D G, Mortimer P P, Blake D R, Woolf A D, Cohen B J, Bacon P A. Human parvovirus arthropathy. Lancet 1985; i: 419-21.

3 Dijkmans B A C, van Elsacker-Niele A M V, Salimans M M M, van Albada-Kuipers G A, De Vries E, Salimans M M M, van Albada-Kuipers G A, De Vries E,
Weiland H T. Human parvovirus B19 DNA in synovial Weiland H T. Human parvovirus B19
fluid. Arthritis Rheum 1988; 31: 279-81.

4 Kandolf R, Kirschner P, Hofschneider P H, Vischer T L. Detection of parvovirus in a patient with "reactive arthritis" by in situ hybridization. Clin Rheumatol 1989; 8: $398-401$.

5 Woolf A D, Campion G V, Chishick A, et al. Clinical manifestations of human parvovirus B19 in adults. Arch Intern Med 1989; 149: 1153-6.

6 Foto F, Saag K G, Scharosch L L, Howard E J, Naides S J. Parvovirus B19-specific DNA in bone marrow from B19 arthropathy patients: evidence for B19 virus persistence. F Infect Dis 1993; 167: 744-8.

7 Saal J G, Steidle M, Einsele H, Müller C A, Fritz P Zacher J. Persistence of B19 parvovirus in synovial membranes of patients with rheumatoid arthritis. Rheumatol Int 1992; 12: 147-51.

8 Nocton J J, Miller L C, Tucker L B, Schaller J G. Human parvovirus B19-associated arthritis in children. $\mathcal{F}$ Pediatr 1993; 122: 186-90

9 Cassinotti P, Weitz M, Siegl G. Human parvovirus B19 infections: routine diagnosis by a new nested polymerase chain reaction assay. $\mathcal{F}$ Med Virol 1993; 40: 228-34.

10 Shade R O, Blundell M C, Cotmore S F, Tattersall P, Astell $C$ R. Nucleotide sequence and genome organization of human parvovirus B19 isolated from the serum ization of human parvovirus B19 isolated from the serum
of a child during aplastic crisis. $\mathcal{F}$ Virol $1986 ; 58: 921-36$.

11 Cohen B J, Buckley M M. The prevalence of antibody to human parvovirus B19 in England and Wales. $f$ Med Microbiol 1988; 25: 151-3.

12 Schwarz T F, Gürtler L G, Zoulek G, Deinhardt F, Roggendorf $M$. Seroprevalence of human parvovirus B19 infection in Sao Tomé and Principe, Malawi and Mascarene islands. Int $\mathcal{f}$ Med Microbiol 1989; 271: 231-6.

13 Kurtzman G J, Cohen B J, Field A M, Oseas R, Blaese $R$ M, Young $N$ S. Immune response to $B 19$ parvovirus and an antibody defect in persistent viral infection. 7 Clin Invest 1989; 84: 1114-23.

14 Anderson M J, Higgins P G, Davis L R, et al. Experimental parvoviral infection in humans. $\mathcal{f}$ Infect Dis 1985; 152: 257-65.

15 Cohen B J, Mortimer P P, Pereira M S. Diagnostic assays with monoclonal antibodies for the human serum parvovirus-like virus (SPLV). F Hyg 1983; 91: 113-30. 